\title{
Relief as an important factor in determining priority landscapes: a case study on Polish landscape parks
}

\begin{abstract}
The practical problems of implementing the Regulation on Landscape Audits (European Landscape Convention, ELC) in Poland are discussed through the topic of landscape relief, on an example of landscape classification of three of Poland's landscape parks. In the existing landscape typologies, various criteria are proposed, in which relief is usually considered to be one of the leading components.

The study was carried out for the purposes of the Landscape Parks Conservation Plans, based on a comparison of the method under the Principles of Landscape Audits and the authors' method. The results indicate that the landscape types set out in the regulation insufficiently take relief into account, leading to omitting the local specific nature of the terrain. The essential attributes of the terrain in the analysed parks are the morphometry of relief and its genesis. Relief helps to determine the landscape types that are more related to the terrain.
\end{abstract}

Keywords

Relief typology • landscape conservation • applied geomorphology• landscape audit

(C) University of Warsaw - Faculty of Geography and Regional Studies
Piotr Wałdykowski $\mathbb{C}$, Joanna Adamczyk $\mathbb{C}$, Agata Cieszewska $\mathbb{C}$

Institute of Environmental Engineering, Department of Landscape Architecture,

Warsaw University of Life Sciences SGGW, Poland

e-mail: piotr_waldykowski@sggw.pl

e-mail: joanna_adamczyk@sggw.pl

e-mail: agata_cieszewska@sggw.pl

Received: 23 August 2019

Accepted: 10 December 2019
Introduction

Relief was one of the earliest landscape components to be classified in Europe. The initial assumptions of relief classification appeared in 1650 (Varenius 1650), although the majority of the research on relief classification for various purposes was conducted in the 19th century. The criteria used were physiognomic assumptions (Ritter 1826, Naumann 1850), the origin of forms and types of relief (Peschel 1869) and the systematics of morphogenetic factors (Richthofen 1886). In Western Europe, the dominant classification of relief was in terms of morphogenetics and genetics (Davis 1889, 1900; Lobeck 1939).

Apart from the typological classification, it was also essential to create regional divisions. Geomorphological rationalisations were the basis for later physico-geographical regionalisation. In Poland, the concepts of such divisions were initiated by S. Staszic (1815) and W. Pol (1851). Orographic criteria related to the layout of the belts of Polish relief dominated. The orographic approach was the basis for the physiognomic division of relief, supplemented by the genetic approach, which led to the identification of "Landscapes of Poland" (Smoleński 1912). The first regional division of Poland was based on geomorphological criteria emphasising the types of relief (Lencewicz 1922). In later studies in various parts of Europe, the emerging regional typologies of the landscape also referred to the perception of landscape concerning relief (e.g. Tricart 1965, Demek 1976). The studies dealing with the problem of physico-geographical regionalisation in Poland directly referred to geomorphology and the geology of regions in the underlying assumptions of classification (Kondracki 1969, Ostaszewska et al. 2009). Poland is an example of the strong relationship between geological structure and relief perceived in scientific studies. J. Kondracki (1969) in particular, as the author of the physicogeographical regionalisation of Poland used today, attempted to systematise the terms used to describe various forms of land relief (e.g. lowlands, plains, hills). He has argued that the typological classification of forms must take into account the internal structure of the forms, the modelling process related to climate, and their geological age (Kondracki 1981). In the typology of landscape classification in the Polish Lowlands, the physiognomy of relief was indicated as an essential criterion (Bartkowski 1974), with particular attention paid to the precise definition of the role of slopes and sides, land gradients and the typology of plains and lowlands (Richling 1981).

The introduction of a new classification of landscapes comes as a result of implementing the European Landscape Convention (ELC 2000), which Poland signed in 2004. It is also necessary to introduce legal solutions for landscape protection. Article 6 of the ELC 2000 sets out the need to identify and assess landscapes, which requires the introduction of a new classification. Each EU Member State that has signed the Convention may introduce its own method of determining the landscape, which leads to significant differences between nations in their proposed landscape classifications (Wascher 2005). The adopted classifications should distinguish elements of the natural environment, as well as historical and cultural elements that should be given equal importance.

Among the various criteria proposed, the most common landscape attributes adopted in Europe are the natural attributes of the landscape, in particular: relief, geological structure and soil (Majchrowska 2008). A landscape audit considers a wider range of 
problems than delimitation of landscape types based on terrain. However, relief is one of the landscape components that, if taken into account, enables the creation of logical spatial boundaries within most of the features of the natural environment.

In Poland, the idea of landscape classification was adopted upon Poland's accession to the European Union in 2004 as the European Landscape Convention (ELC 2000) entered into force. In 2015, Poland adopted the 24 April 2015 Act on the Amendment of Certain Acts in Connection with the Strengthening of Landscape Protection Tools (the "Act"). The Act sets out the need to prepare a landscape audit for the whole of Poland, through the identification of current landscapes in each administrative region. The main element of the audit is to identify the particularly valuable landscape fragments, called priority landscapes. In recent research, the scope of landscape identification and assessment (Solon et al. 2014) and the determination of the range of landscape analyses for landscape protection (e.g Czochański 2016, Myga-Piatek et al. 2016, Pukowiec-Kurda et al. 2017, Michalik-Śnieżek et al. 2017, Badora et al. 2018), as well as the implementation of landscape audits on a local scale (Badora et al. 2018), were all emphasised. The last stage of legal regulation concerning landscape protection was the introduction of the Regulation on the Preparation of Landscape Audits of 11 January 2019 (the "Regulation"). This contains detailed guidelines on how to conduct a landscape audit. The Regulation introduces a mandatory instruction that unifies methodological assumptions, including the classification of landscapes.

This article discusses problems with the methodology of prioritising landscape identification, with respect to the role of relief determining landscape types. This was verified using examples of landscape analysis of three landscape parks in Poland (Figure 1). The Parks analysed are part of the nature protection system in Poland. Their conservation status corresponds to IUCN category $\checkmark$ protected areas: protected landscapes/seascapes (Dudley et al. 2013), also referred to as "regional parks" in other countries. The research questions focused on the proposed division of relief types in the process of separating current and priority landscapes on a local scale. We were mainly interested in whether the proposed landscape classifications (especially regarding relief) respond to the needs of practical studies. In our case, this procedure was necessary for the preparation of Landscape Parks' Conservation Plans. In this type of document, the actual types of landscapes and priority landscapes are indicated, in accordance with the provisions of the Act.

\section{Material and Methods}

In order to show the results of the different ways in which relief is included in the landscape classification, a comparison was made between two approaches: the first based on the Principles of Landscape Audit according to the Regulation, and the second based on the authors' method of identifying current and priority landscapes (Cieszewska et al. 2018).

To visualise the results, three landscape parks were analysed within the landscape types identification and assessment framework prepared for protection plans. Each of the parks protects unique landscape values. For comparison purposes parks were selected for the differences in their landscape features in post-glacial areas (the Vistula glaciation zone Brudzeń Landscape Park, the Odra glaciation zone - Chojnów Landscape Park) and the highlands (Kozubów Landscape Park). Brudzen Landscape Park is located close to the city of Płock. It protects the valley of the Skrwa River, together with areas of post-glacial uplands that are adjacent to the valley. The unique value of the park is its outstanding terrain denivelations and clear morphological edges separating various genetic levels of the relief. Chojnów Landscape Park protects the deciduous forest landscape on a post-glacial upland near the Warsaw Metropolitan Area. Typical for this area are slight denivelations, the largest of which result from the fact that the park covers a fragment of the post-glacial upland slope descending into the Vistula valley. Slightly cut river valleys also diversify the landscape. Kozubów Landscape Park is located to the south of the city of Kielce $(200 \mathrm{~km}$ south of Warsaw). It protects the relief of marl hills covered with loess. All three landscape parks are dominated by similar forms of land cover, such as forest, arable land and rural built-up areas. For each park, a set of two maps showing the division of landscape parks was compiled: (1) set out in accordance with the Regulation of 2019, and (2) using the method developed by the authors for the purposes of protection plans for these parks (Cieszewska et al. 2018). The basis for the studies was the local scale $(1: 10000)$. The first stage was to identify landscape units, taking into account the coverage/use of the land together with the relief. This study presents the results of this stage. To determine the priority landscapes, which goes beyond the scope of this article, it is necessary to take into account additional physiognomic and cultural criteria.

At the time of preparing these documents for the landscape parks (2017-2018), there was no legal basis under the Regulation in force, but various draft versions were available as instructions (e.g. Solon et al. 2014) and recommendations for landscape audit (Niedźwiecka-Filipiak et al. 2017). In the authors' method, these studies were taken into account only in the general assumptions of classifying landscape types, their characteristics and assessment leading to the identification of priority landscapes. For the same areas, a list of landscape types was prepared according to the author's method, based on the materials mentioned above, adjusted to the needs of preparing protection plans. Then the results were compared with the landscape types resulting from the Regulation (Table 1). The compilation shows how different the types of landscape may be in terms of land relief and land cover when applied to practical studies. In the case of the author's method, the difference results from the morphometric and morphogenetic variability of land relief and land cover (Cieszewska et al. 2018). In the case of classification under the provisions of the Regulation of 2019, the land cover was considered as the landscape background and the relief characteristics act only as a supplement to the generalised landforms.

\section{Results}

A comparison of two methods of determining the types of landscape units in three different areas showed significant variances in the number of divisions between the authors' study and that carried out on the basis of the Regulation. (Tab 2).

In Brudzeń Landscape Park, divisions made according to the Regulation indicate the existence of only two categories of relief - valleys and plains. For the purposes of the protection plan, it was necessary to extend the scope of the land relief delimitation (Figure 2) by additional types: long slopes of wide river valleys (with a length of $>200 \mathrm{~m}$ ) and narrow valleys with short slopes (dry valleys and ravines with steep slopes of length 50-200 m), which have no corresponding types under the Regulation. (In the Regulation they are only mentioned in the detailed characteristics of landscape units). As a result, they would not be taken into account in the classification of landscape types. Compared to the Regulation, the identification of landscape types for a conservation plan is primarily based on a more detailed differentiation of relief and detailed coverage of the land (Figure 2).

On a map prepared further to the Regulation, the variability of the landscape background (using land cover) does not refer to the relief, which is visible in the Skrwa River valley. Morphological boundaries are not taken into account. Based on the land cover only, it is not possible to take into account the valley slopes. To 


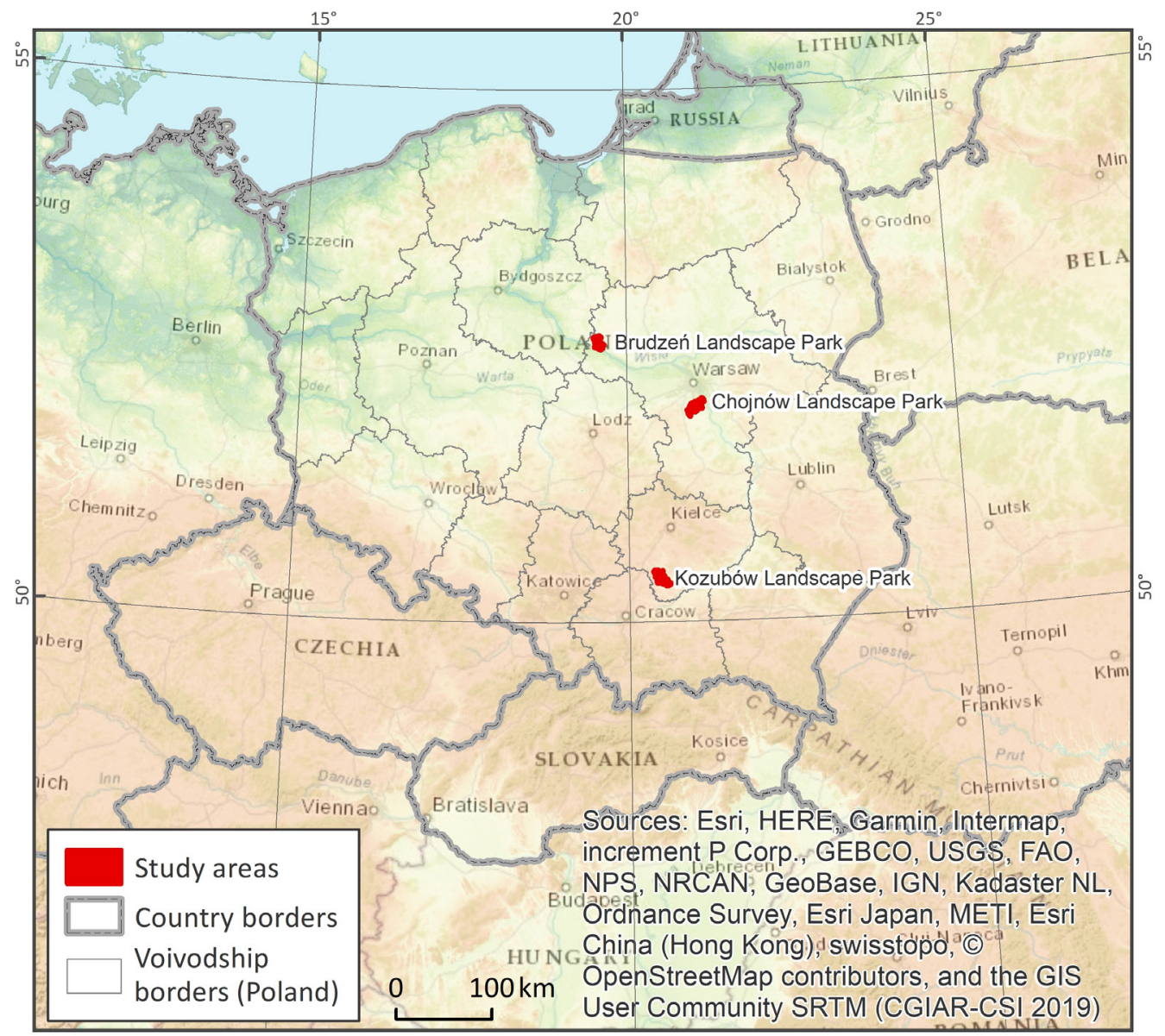

Figure 1. Location of study area in the context of Poland

Table 1. Classification of relief, typology and identified landscape types, according to: $A$-Annex 2 of the Regulation on the Principles of Preparing Landscape Audits of 11 January 2019 (source: own work); B - The method used in preparing Landscape Parks' Conservation Plans (source: own work based on Cieszewska et al. 2018)

\begin{tabular}{|c|c|c|c|}
\hline \multicolumn{2}{|r|}{ Relief typology } & \multicolumn{2}{|r|}{ Identified landscape types, abbreviations from maps } \\
\hline & & & Brudzeń Landscape Park \\
\hline \multirow{6}{*}{ A } & \multirow{6}{*}{$\begin{array}{l}\text { - Plains } \\
\text { - Valleys }\end{array}$} & \multirow{6}{*}{ A } & LB - Forested landscape on coniferous habitats in valleys/on plains \\
\hline & & & LL - Forested landscape on deciduous habitats in valleys/on plains \\
\hline & & & LOB - Forested landscape on riparian and swampy habitats in valleys \\
\hline & & & $\begin{array}{l}\text { WRm - Rural landscape with predomination of agricultural land use mosaic with small-sized } \\
\text { plots on plains }\end{array}$ \\
\hline & & & WRs - Rural landscape with mosaic of agricultural land use with medium-sized plots on plains \\
\hline & & & WZ - Rural landscape with predomination of rural settlements on plains \\
\hline \multirow{9}{*}{ B } & \multirow{9}{*}{$\begin{array}{c}\text { - long slopes of wide river } \\
\text { valleys } \\
\text { - plains of postglacial } \\
\text { upland } \\
\text { - wide river valleys with } \\
\text { short slopes } \\
\text { - narrow valleys with } \\
\text { short slopes }\end{array}$} & \multirow{9}{*}{ B } & WL - Forested landscape on postglacial upland plains \\
\hline & & & WMZ - Mosaic landscape of built up areas and fields on postglacial upland plains \\
\hline & & & WMP - Mosaic landscape of fields and built up areas on postglacial upland plains \\
\hline & & & WP - Fields landscape on postglacial upland plains \\
\hline & & & WZ - Settlement's landscape on postglacial upland plains \\
\hline & & & DwMkz - Mosaic of forests, meadows and fields in wide river valleys with short slopes \\
\hline & & & DsMLkz - Mosaic of forests, meadows and fields in narrow valleys with short slopes \\
\hline & & & DZL - Forested landscape on long slopes of wide river valleys \\
\hline & & & DZM - Mosaic landscape of fields and forest on long slopes of wide river valleys \\
\hline
\end{tabular}


Continued Table 1. Classification of relief, typology and identified landscape types, according to: A-Annex 2 of the Regulation on the Principles of Preparing Landscape Audits of 11 January 2019 (source: own work); B - The method used in preparing Landscape Parks' Conservation Plans (source: own work based on Cieszewska et al. 2018)

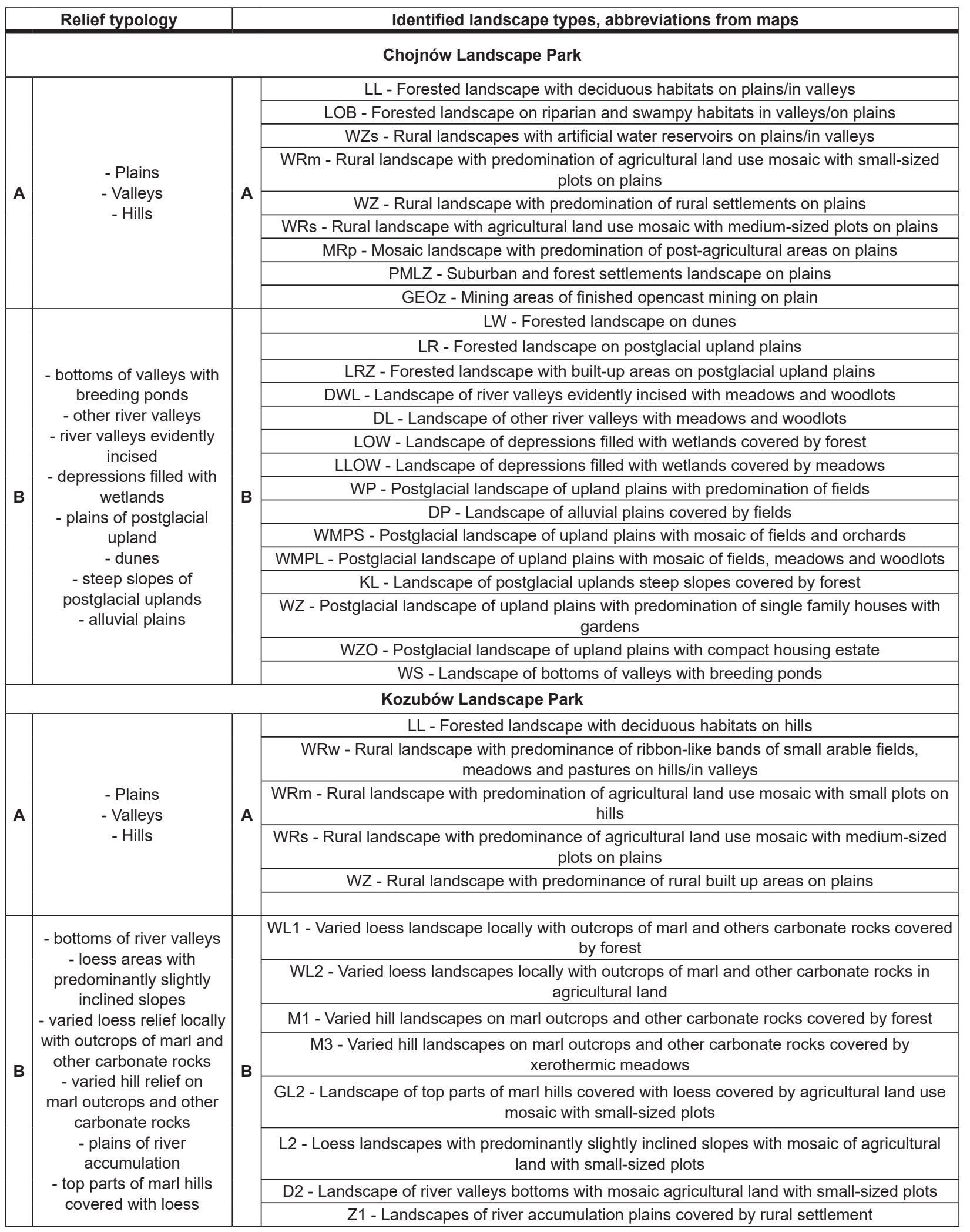



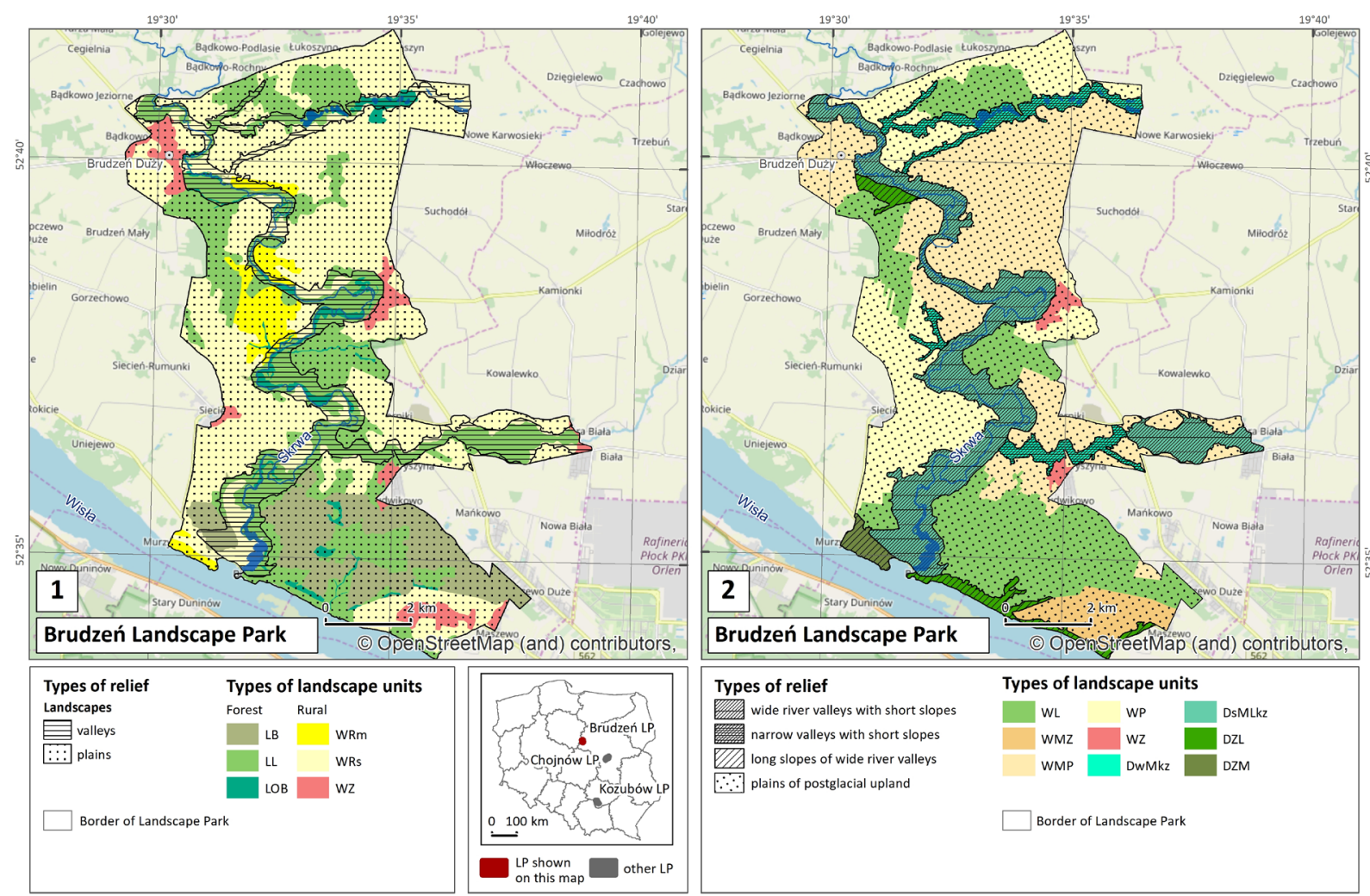

Figure 2. A comparison of landscape types as a result of a landscape audit for the Brudzeń Landscape Park Conservation Plan (source: own work and (C) OpenStreetMap contributors https://www.openstreetmap.org/copyright) A - Annex 2 of the Regulation on the Principles of Preparing Landscape Audits of 11 January 2019 (source: own work); B - Used in Landscape Parks' Conservation Plans (source: own work, based on Cieszewska et al. 2018). (Abbreviations explained in Table 1.)

provide a more accurate presentation of entire valleys, it was necessary to combine the forms of land cover/use in a way that emphasises the presence of the valley (wide valleys with short slopes) (Figure 2). The delimitation of long slopes of wide river valleys and narrow valleys with short slopes made it possible to emphasise the borders of glacial uplands, which are a crucial physiognomic element influencing the attractiveness of the landscape. These differences can be observed mainly in the surroundings of the Vistula valley, where the long slopes of the upland, according to the Regulation, might simply be a part of the plain (Figure 2)

In the Chojnów Landscape Park, the relief divisions based on the Regulation are limited to three categories: valleys, plains and hills (Figure 3). The landscape of the Park is dominated by indented plains and valleys not strongly cut, in contrast to the Brudzen Landscape Park. The following types were determined to ensure that the relief types correspond to the specific nature of the terrain: bottoms of valleys with breeding ponds. It was found that there were no references to these types in the Regulation. To improve readability, the category of hills had to be specified as dunes, and the genesis was added to the indicated plains. To enhance the physiognomic legibility of the valleys, they were divided into two categories: "River valleys evidently incised" and "other river valleys". The map of Chojnów Landscape Park confirms that a landscape background based on terrain coverage does not help to define landscape boundaries. The extent of the priority landscapes obtained refers to more detailed terrain boundaries, which better reflect the physiognomic specifics of the area (Figure 3). In the authors' study, the land cover/ use boundaries were adjusted to the relief, which resulted in a more orderly division of landscape types. The range of priority landscapes in the Chojnów Landscape Park is equally concerned with the diversity of land cover, such as relief. This is an effect of the predominance of the landscape of plains.

In Kozubów Landscape Park, the division of the relief according to the Regulation indicates only the categories of valleys, plains and hills. The key value of the Park was stressed, which is the existence of areas of limestone hills covered with loess. It was therefore necessary to distinguish between additional categories: "loess areas with predominantly slightly inclined slopes" and "various loess relief with outcrops and other carbonate rocks" (Figure 4). Based on the presented examples, there are visible differences between the areas, with different main types of relief. The classification of the relief adopted in the Regulation of 2019 (Annex 2) is over-simplified. If the landscape classifications of parks were drawn up in this way, they would be dominated by general types of relief: plains and valleys. According to the definitions contained in the Regulation, the term valley is understood only as a river valley with a flat, relatively wide bottom. Plains cover all flat areas outside of valleys, regardless of their genesis. In Chojnów Landscape Park, additional hills would be included, along with hills in the Kozubów Landscape Park. In the relief divisions adapted for the needs of the landscape protection plans, a much more comprehensive range of types of relief was taken into consideration, resulting from the specific nature of the local areas.

\section{Discussion and Conclusions}

In the Polish Regulation on Landscape Audits, relief is an essential element, but the key division of landscapes into 

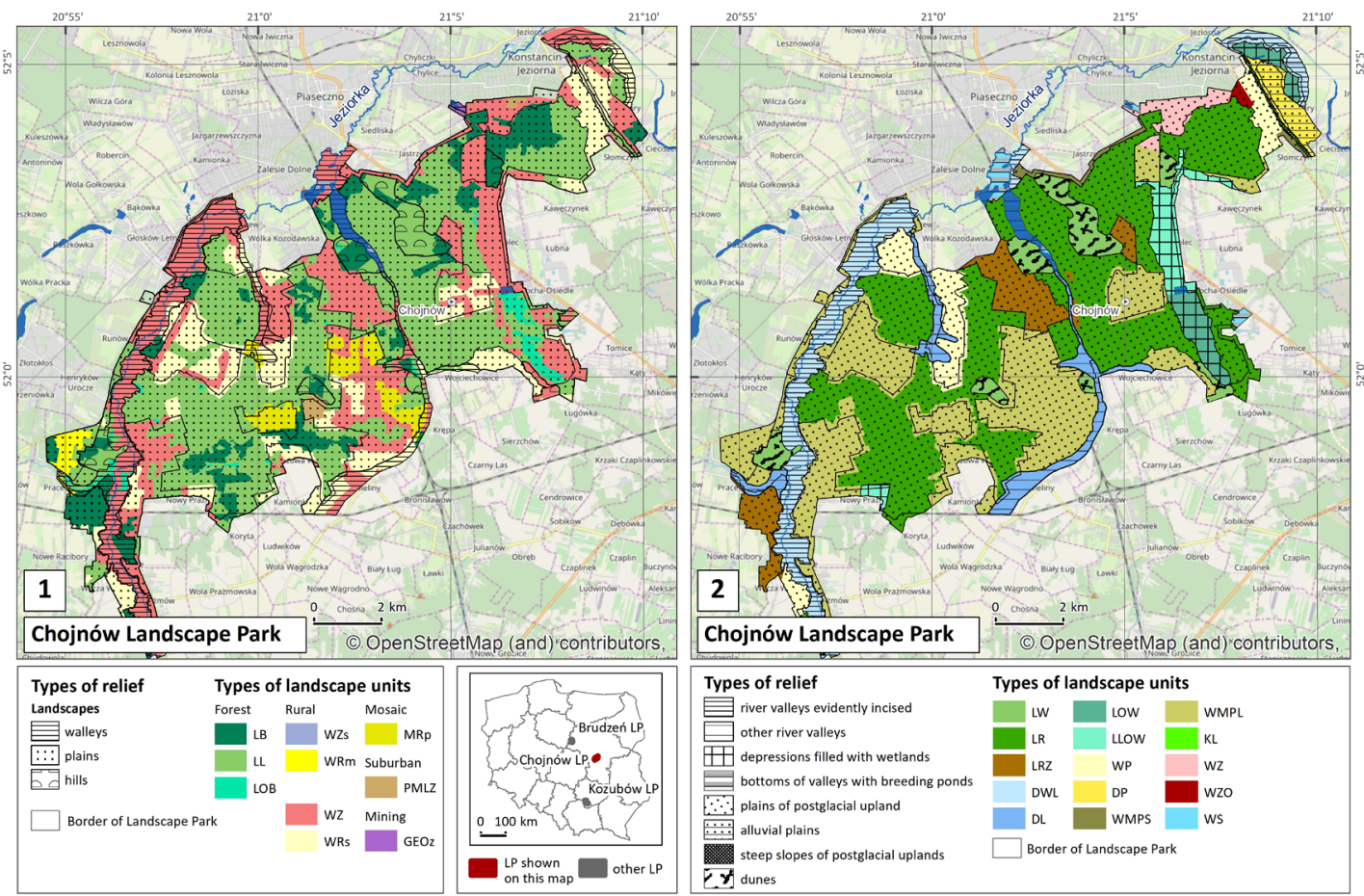

Figure 3. Comparison of landscape types as a result of a landscape audit for the Chojnów Landscape Park Conservation Plan (source: own work and (C) OpenStreetMap contributors https://www.openstreetmap.org/copyright) A - Annex 2 of the Regulation on the Principles of Preparing Landscape Audits of 11 January 2019 (source: own work); B - The method used in Landscape Parks' Conservation Plans (source: own work based on Cieszewska et al. 2018). (Abbreviations explained in Table 1.)
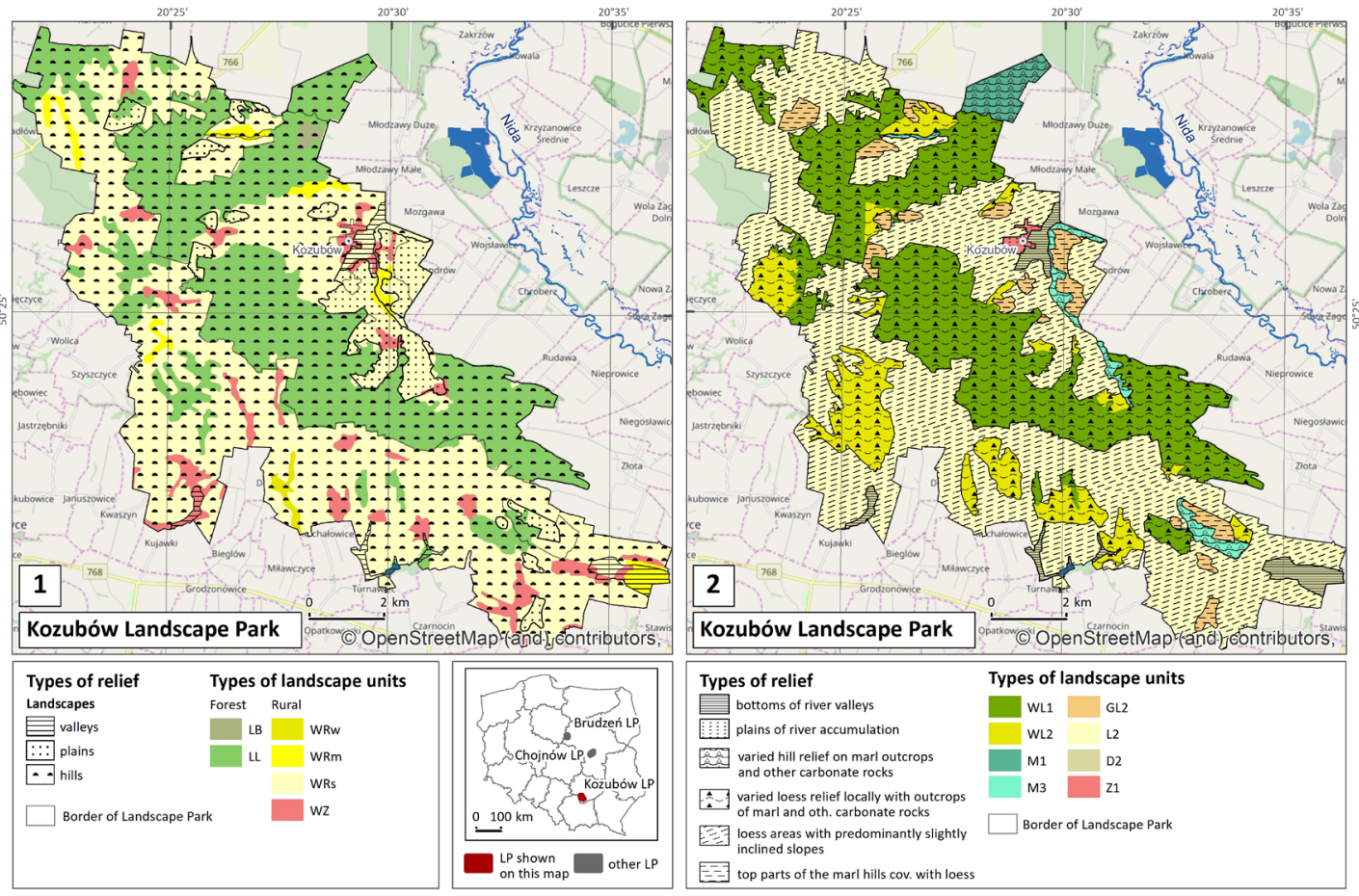

Figure 4. Comparison of landscape types as a result of a landscape audit for the Kozubów Landscape Park Conservation Plan (source: own work and (C) OpenStreetMap contributors https://www.openstreetmap.org/copyright) A - Annex 2 of the Regulation on the Principles of Preparing Landscape Audits of 11 January 2019 (source: own work); B - the method used in Landscape Parks' Conservation Plans (source: own work based on Cieszewska et al. 2018). (Abbreviations explained in Table 1.) 
MISCELLANEA GEOGRAPHICA - REGIONAL STUDIES ON DEVELOPMENT

Vol. $24 \cdot$ No. $1 \cdot 2020 \cdot$ pp. 42-50 •ISSN: 2084-6118 • DOI: $10.2478 /$ mgrsd-2020-0003

Table 2. Comparison of the number and types of divisions between Annex 2 of the Regulation on the Principles of Preparing Landscape Audits of 11 January 2019 and the authors' method used in Landscape Parks Conservation Plans.

\begin{tabular}{|c|c|c|c|c|c|}
\hline \multirow[t]{2}{*}{$\begin{array}{l}\text { Landscape } \\
\text { Park } \\
\end{array}$} & \multicolumn{2}{|c|}{$\begin{array}{c}\text { Annex } 2 \text { of the Regulation of } 11 \\
\text { January } 2019\end{array}$} & \multicolumn{2}{|c|}{$\begin{array}{l}\text { Method used in Regional } \\
\text { Parks Conservation Plans }\end{array}$} & \multirow{2}{*}{$\begin{array}{l}\text { Summary of differences between the } \\
\text { authors' method and the Regulation }\end{array}$} \\
\hline & $\begin{array}{c}\text { No of landscape } \\
\text { types }\end{array}$ & $\begin{array}{c}\text { No of relief } \\
\text { types }\end{array}$ & $\begin{array}{c}\text { No of } \\
\text { landscape } \\
\text { types }\end{array}$ & $\begin{array}{c}\text { No of relief } \\
\text { types }\end{array}$ & \\
\hline Brudzeń & 6 & 2 & 9 & 4 & $\begin{array}{c}\text { The ranges of valleys are more precisely } \\
\text { defined. } \\
\text { The main areas of the plains have been } \\
\text { retained. } \\
\text { Other types are different. }\end{array}$ \\
\hline Chojnów & 10 & 3 & 15 & 8 & $\begin{array}{c}\text { The ranges of valleys are more precisely } \\
\text { defined. } \\
\text { The main areas of the plains have been } \\
\text { retained. } \\
\text { Other types are different. }\end{array}$ \\
\hline Kozubów & 6 & 3 & 8 & 6 & $\begin{array}{c}\text { The ranges of the valleys are similar. } \\
\text { Other types are different. }\end{array}$ \\
\hline
\end{tabular}

types is to be made based on land cover/use, referred to as the landscape background. The types of relief included in the Regulation should be considered inadequate to meet the specific nature of the Polish landscape. The relief is only treated as an additional element of the landscape background, included in the description.

Before the introduction of the Regulation (2019), some authors suggested that the proposed classification of the landscape should be an open system, allowing for the addition of locally specific subtypes of landscape, and taking into account the changes taking place. This was justified by the fact that some types of Polish landscape are associated with repetitive landscapes (e.g. forests, residential or industrial landscapes), which may be accompanied by landscapes strongly associated with features of micro-regions, i.e. also with features of land relief (Czochański 2016). It was stressed that the landscape types and subtypes proposed in the Instruction to Landscape Audits (Solon et al. 2014) refer to the national level, which will make it impossible to depict locally-significant landscape elements in detail (Czochański 2016). Studies testing the landscape audit carried out in the mountainous area of Beskid Śląski also led to the conclusion that, in the Landscape Audit Manual, the identification of landscapes for the needs of the regional scale was excessively simplified. A more useful approach on a local scale is a detailed approach that could bring additional cognitive and practical value (Badora et al. 2018), for example on the scale of the Landscape Park Conservation Plan. It was recognised that landscape division criteria based on a "physiognomic type of landscape" might be more useful for less diversified landscapes, but in upland and mountainous landscapes this approach simplifies landscape typology too much (Badora et al. 2018). In studies on delimitation of landscape types (Solon et al. 2014) the method was tested for the upland part of Poland using landscape indicators in the context of assessing the degree of landscape transformation (PukowiecKurda et al. 2016).

Another attempt to apply the analysis of relations between landscape indicators was made in the region of Częstochowa (Pukowiec-Kurda et al. 2017). It was found that in the areas undergoing strong anthropogenic transformations, the land use structure (reflected by the elements of land cover) does not refer to the physical and geographical outline of the units, which further increases the number of landscape units. If there is a risk of creating landscape units without taking into account physical-geographical divisions (Myga-Piatek et al. 2016), it also leads to the omission of geomorphological classifications when delimiting detailed landscape units. The results of landscape analyses in three landscape parks showed that the detailed land cover/use of the site should be related to the equally detailed relief. The geomorphological classification should therefore be carefully taken into account in terms of morphometry, genesis and structure (geological structure).

In the tradition of landscape studies, the features of the relief were identified based on the concept of landscape physiognomy over a long period. Identifying landscape types without relief playing a leading role, as it is proposed in the Polish Regulation, can make it difficult to determine the extent of priority landscapes. A significant problem may concern areas with dynamic relief, such as highlands or postglacial uplands. Accepting the only morphometric criterion in the relief classification, as in the Regulation of 11 January 2019, should be considered insufficient. It does not include, among other things, the concepts of morphological edges defined by the slopes in more detailed studies. The inability to take into account the slopes makes it impossible to determine the boundaries of landscape types precisely. A separate problem is the lack of references to the genesis of relief. The morphometric criterion does not allow smaller forms, such as dunes or terrain depressions, to be distinguished. These are objects that are indicative in association with other components of the natural environment, such as water, soil or vegetation. If the land cover/use is similar, regardless of the region of Poland, and the outstanding landscape features associated with the relief are omitted at the stage of delimitation of landscape units, then it becomes impossible to identify the critical features of the priority landscapes.

The importance of relief is crucial in landscape analysis, including for the classification of landscape types, as has been proven in numerous research studies. In practice, landscape boundaries based on relief have a significant impact on the development of areas, and therefore should be taken into account as the main factor of landscape assessment, and subsequently in spatial planning.

\section{ORCID}

Piotr Wałdykowski (D) https://orcid.org/0000-0002-7493-6405 Joanna Adamczyk (iD https://orcid.org/0000-0002-8026-2734 Agata Cieszewska (1) https://orcid.org/0000-0002-3647-1539 
Badora, K \& Jakubiec, U 2018, 'Zastosowanie metodyki audytu krajobrazowego do identyfikacji krajobrazów w skali lokalnej na przykładzie gminy Szczyrk' [Application of landscape audit methodology for landscape identification on local scale an example of Szczyrk commune], Prace Komisji Krajobrazu Kulturowego, vol. 39(1), pp. 25-40.

Bartkowski, T 1974, Zastosowanie geografii fizycznej [Application of physical geography], Wydawnictwo Naukowe PWN, Warszawa.

Chmielewski, TJ, Myga-Piątek, U \& Solon, J 2015, 'Typologia aktualnych krajobrazów Polski' [Typology of current Polish landscapes], Przegląd Geograficzny, vol. 87, pp. 377-408.

Cieszewska, A, Wasilewski, M, Giedych, R \& Wałdykowski, P 2018, 'Priority landscapes in Brudzeń Landscape Park Conservation Plan', Land Reclamation, vol. 50(4), pp. 339352.

Czochański, JT 2016, ‘Przemiany krajobrazowe Gdyni - przegląd typów i zmian krajobrazów w dziewięćdziesięcioleciu istnienia miasta' [Gdynia's landscape transformation - an overview of landscape types and changes over the 90 years of the city's existence], Problemy Ekologii Krajobrazu, vol. 41, pp. 211-225.

Davis, W 1889, 'The geographical cycle', The Geographical Journal, vol. 14, no. 5, pp. 481-504.

Davis, W 1900, 'Physigraphic terminology with special reference to lands forms', Science, vol. 11.

Demek, J 1976, Handbuch der Geomorphologischen Detailkartirung [Handbook of geomorphological detail mapping], Hirt, Wien.

Dudley, N, Shadie, P \& Stolton, S 2013, Guidelines for applying protected area management categories including IUCN WCPA best practice guidance on recognising protected areas and assigning management categories and governance types, Gland. Available from: <https://portals. iucn.org/library/node/30018>. [5 November 2013].

European Landscape Convention (ELC), Florence 2000, Council of Europe ETS No 176.

Kondracki, J 1976, Podstawy regionalizacji fizycznogeograficznej [Basics of physicogeographical regionalization], Wydawnictwo Naukowe PWN, Warszawa.

Kondracki, J 1981, Geografia fizyczna Polski [Physical geography of Poland], Wydawnictwo Naukowe PWN, Warszawa.

Krajewski, P \& Mastalska-Cetera, B 2016, 'Rola audytu krajobrazowego w kontekście zasad funkcjonowania wybranych obszarów chronionych' [Role of landscape audit in the context of functioning principles of selected protected areas], Problemy Ekologii Krajobrazu, vol. 43, pp. 63-71.

Lencewicz, S 1922, Kurs geografji Polski [Polish geography course], Główna Księgarnia Wojskowa, Warszawa.

Lobeck, A 1939, Geomorphology, McGraw Hill Book Company, New York.

Majchrowska, A 2008, 'Systematyzacja krajobrazów w wybranych krajach europejskich' [Systematization of landscapes in European countries], Problemy Ekologii Krajobrazu, vol. 20, pp. 127-134.

Mastalska-Cetera, B \& Krajewski, P 2014, 'Plany ochrony parku krajobrazowego, jako narzędzie wspomagające zrównoważony rozwój' [Landscape park conservation plans as a tool supporting sustainable development], Problemy Ekologii Krajobrazu, vol. 37, pp. 147-156.

Michalik-Śnieżek, M \& Chmielewski, TJ 2017, 'Krajobrazy aktualne Kazimierskiego Parku Krajobrazowego' [Current landscapes of the Kazimierz Landscape Park], Prace Komisji Krajobrazu Kulturowego, vol. 36, pp. 47-61.
Myga-Piatek, U, Nita, J, Pukowiec-Kurda, K \& Sobala, M 2016, 'Audyt krajobrazowy dla Częstochowy' [Landscape audit for Częstochowa], Przegląd Urbanistyczny, vol. 12, pp. 25-28.

Naumann, KF 1850, Lehrbuch der Geognosie [Textbook of Geognosy], Engelmann, Lipsk.

Niedźwiecka-Filipiak, I, Ozimek, P, Akincza, M, Kochel, L, Krug, D, Sobota, M \& Tokarczyk-Dorociak, K 2017, Rekomendacje w zakresie prowadzenia analiz krajobrazowych na potrzeby wyznaczania stref ochrony krajobrazu [Recommendations in the field of landscape analysis for the purposes of designating landscape protection zones], Generalna Dyrekcja Ochrony Środowiska, Warszawa.

OpenStreetMap contributors. Available from: <https://www. openstreetmap.org/copyright>. [5 November 2013].

Ostaszewska, K \& Richling, A 2009, Geografia fizyczna Polski [Physical geography of Poland], Wydawnictwo Naukowe PWN, Warszawa.

Peschel, O 1869, Neue Probleme der Vergleichenden Erdkunde als Versuch einer Morphologie der Erdoberfläche [New problems of comparative geography as an attempt of a morphology of the earth's surface], Duncker \& Humblot, Lipsk.

Pol, W 1851, Rzut oka na północne stoki Karpat [A glance at the northern slopes of the Carpathians], Czcionkami drukarni Czasu przy ulicy Szczepańskiej nr. 369, Kraków.

Pukowiec-Kurda, K \& Myga-Piatek, U 2017, 'Application of new methods of environment analysis and assessment in landscape audits - case studies of urban areas like Czestochowa, Poland', "Environmental Engineering" 10th International Conference, Vilnius Gediminas Technical University Lithuania, 27-28April2017, pp. 1-8.Available from: <https://rebus.us.edu.pl/bitstream/20.500.12128/9156/1/ Pukowiec-Kurda_Application_of_new_methods_of_ environment_analysis.pdf $>$. [20 August 2019].

Pukowiec-Kurda, K \& Sobala, M 2016, 'Nowa metoda oceny stopnia antropogenicznego przekształcenia krajobrazu na podstawie metryk krajobrazowych' [A new method of assessing the degree of anthropogenic landscape transformation based on landscape metrics], Prace Komisji Krajobrazu Kulturowego, vol. 31, pp. 71-84.

Raszka, B \& Kasprzak, K 2017, 'Park krajobrazowy - możliwości ochrony przestrzeni' [Regional park - possibilities of the area protection], Polish Journal for Sustainable Development, vol. 21 (1), pp. 57-68.

Richling, A 1981, Przewodnik do badań z zakresu geografii fizycznej ogólnej [Guide to research in the field of general physical geography], Wydawnictwo Uniwersytetu Warszawskiego, Warszawa.

Richthofen, F 1886, Handbuch für Forschugareisende [Handbook for research travelers], Robert Oppenheim, Berlin.

Ritter, K 1826, Studien über die Geographische Stellung und horizontale Ausbraitung der Erdteile [Studies on the geographic position and horizontal extension of the continents], Berlin.

Rozporządzenie z 11 stycznia 2019 w sprawie sporządzania audytów krajobrazowych [Regulation of January 11, 2019 on the preparation of landscape audits], Journal of Laws 2019, item 394.

Smoleński, J 1912, Krajobraz Polski [Landscape of Poland], Wydawnictwo Mortrowicza, Warszawa.

Solon, J, Chmielewski, TJ, Myga-Piątek, U \& Kistowski, M 2014, Zadanie III.1. Opracowanie szczegółowej instrukcji postępowania, prowadzącej wykonawcę audytu od rozpoczęcia prac do pełnego zakończenia. Wersja 02 [Task 
III.1. Developing a detailed instruction manual, leading the auditing contractor from commencement of works to full completion. Version 02], Generalna Dyrekcja Ochrony Środowiska, Warszawa.

Staszic, S 1815, O ziemiorództwie Karpatów i innych gór $i$ równin Polski [About the lands of the Carpathians and other mountains and plains of Poland], Drukarnia Rządowa, Warszawa.

Tricart, J 1965, Principes et methodes de la geomorphologie [Principles and methods of geomorphology], Masson et Cie, Paris.

Ustawa z dnia 24 kwietnia 2015 r. o zmianie niektórych ustaw w związku ze wzmocnieniem narzędzi ochrony krajobrazu [Act of 24 April 2015 on the amendment of certain acts in connection with the strengthening of landscape protection tools], Journal of Laws 2015, item 774.

Varenius, B 1650, Geographia generalis [General Geography], London.

Wascher, DM 2005, European Landscape Character Areas. Typologies, Cartography and Indicators for the Assessment of Sustainable Landscapes, Final Project Report, Project: FP5 EU Accompanying Measure Contract: ELCAI-EVK2CT-2002-80021, Printed by Information Press, Oxford. 